\title{
The Effect of Various Herbicides on Growth of Dioscorea composita (Hemsl.) Under Greenhouse Conditions
}

\author{
Jaime González-Tbáñez and Héctor R. Cibes-Viadé1
}

\section{INTRODUCTION}

Several species of plants belonging to the family Dioscoraceae yield steroids used in the synthesis of cortisone (1).2 One of these, Dioscorea composita (Hemsl.), was introduced recently from Mexico into Puerto Rico. A good-sized plantation has been established at Barrio Quebrada Arenas in the vicinity of Yabucoa.

Weeds constitute a most pressing problem in the cultivation of this new crop. Climatic conditions prevailing in the above-mentioned region are conducive to the luxuriant growth of noxious plants throughout the major part of the year. More than 50 weed species were identified in the area by Mr. R. Woodbury ${ }^{8}$ during a 1963 survey. The fact that laborers are scarce and wages high further aggravates the situation so prospects of good yields are poor unless chemical eradicants are used to keep down the weeds.

Kasasian (2) in Trinidad showed that herbicides such as Simazine, Atrazine, Atratone, Prometone, Prometryne, Amiben and Diuron were very effective for the control of weeds in plantings of edible yam, Dioscorea alata L. Poor weed control was obtained, however, with Neburon, T.C.A., Dalapon and Alipur, while Fenac was noted as injurious to the crop.

An experiment was established in the greenhouses at Rio Piedras to determine primarily the extent to which $D$. composita would tolerate various concentrations of some of the above mentioned herbicides. It was considered that inasmuch as both yam species belong to the same genus, a possibility might exist that composita would be tolerant to one or more of the these chemicals.

1 Assistant Biologist and Plant Physiologist, respectively, Agricultural Experiment Station, Mayagüez Campus, University of Puerto Rico, Río Piedras, P.R. Authors are grateful to Mr. Joseph Sollins of Phytogen Products, Inc. for providing tubers of Dioscorea composita and for taking the pictures shown herein. Thanks are also due to Mr. Eduardo Alsina for his unbiased interest and aid during the course of these studies. Special thanks are extended to Dr. Julio Bird, Head of the Department of Plant Pathology and Botany, for assistance in the preparation of this manuscript.

2 Numbers in parentheses refer to Literature Cited, p. 333.

- Taxonomist, Agricultural Experiment Station, Mayagüez Campus, University of Puerto Rico, Río Piedras, P.R. 


\section{MATERIALS AND METHODS}

One hundred seedlings of $D$. composita were brought from a private nursery in Cayey to our greenhouse in Rio Piedras. On arrival each seedling was transplanted to a 53/4-inch diameter, perforated, black plastic bag containing sifted soil of the Montones series. This soil is the predominant type in the Quebrada Arenas area. The seedlings were allowed to grow undisturbed for a period of about 11/2 months at the end of which time they were divided into groups of five plants. Each group received one of the following herbicide treatments: Monuron, Diuron, Atrazine, Simazine, or Prometryne applied directly to the surface of the soil with a pipette at the quivalent rates of 2,4 , and 8 pounds per acre. Neburon was similarly applied but at concentrations of 4,8 , and 16 pounds per acre. One group of plants was left untreated. The above-mentioned differential treatments were completed October 10, 1963. For vine support 3-foot long bamboo poles were staked into each bag.

The bags were rearranged at random into five groups of $19 \mathrm{bags}$, each of which had received a different herbicide treatment. This distribution of bags made up a complete block design.

The appearance of the test plants was observed periodically. At the end of 6 months the plants were uprooted and the fresh weight of tops and tuberous roots was recorded. The weight and number of weeds also was recorded.

\section{RESULTS AND DISCUSSION}

The average number and weight of weeds, as well as weight of tuberous roots, is presented in table 1 under the corresponding treatment. At first glance, it can be seen that the growth of weeds was, in general, poor. Apparently, the soil used in this trial had a low weed seed population. In spite of this, the number and weight of weeds were significantly lower in the case of plants treated with herbicides. There were no significant differences between the green weights of the weeds regardless of concentrations applied.

Information obtained in this trial with respect to the relative tolerance of $D$. composita to Simazine, Atrazine, Prometryne, Diuron, Monuron, and Neburon is summarized in the following account:

\section{SUBSTITUTED UREAS}

1. Monuron: This chemical, when applied at the rate of 2 pounds per acre, did not affect the size and weight of the roots. Increasing the herbicide dosage to 4 or 8 pounds per acre, however, greatly reduced the weight of roots ( 50 percent or more). All Monuron concentrations were injurious 
to the foliage of plants. The extent of the injury was closely related to the rate used. At the 2-pound rate symptoms of toxicity were milder than those shown by plants under the effects of the other two concentrations. In general, the leaves of treated plants became flaccid and droopy. This wilting condition was followed by yellowing of the uppermost leaves,

TABLE 1.-Effects of certain herbicides on yield of tubers by Dioscorea composita

(Hemsl.) (D. tepinapensis Uline) and on suppression of weeds associated with this cultivar, under greenhouse conditions 1

\begin{tabular}{|c|c|c|c|}
\hline \multirow{2}{*}{ Treatment } & \multirow{2}{*}{$\begin{array}{l}\text { Average weight of tubers } \\
\text { (5 replicates) }\end{array}$} & \multicolumn{2}{|c|}{$\begin{array}{l}\text { Average number and average green } \\
\text { weight of aerial weed growtth per bag }\end{array}$} \\
\hline & & Number & Weight \\
\hline $\begin{array}{l}\text { 1. Monuron, } 2 \mathrm{lbs} . / \mathrm{A} \\
\text { 2. Monuron, } 4 \mathrm{lbs} . / \mathrm{A} \\
\text { 3. Monuron, } 8 \mathrm{lbs} . / \mathrm{A} \\
\text { 4. Diuron, } 2 \mathrm{lbs} . / \mathrm{A} \\
\text { 5. Diuron, } 4 \mathrm{lbs} . / \mathrm{A} \\
\text { 6. Diuron, } 8 \mathrm{lbs} . / \mathrm{A} \\
\text { 7. Neburon, } 4 \mathrm{lbs} . / \mathrm{A} \\
\text { 8. Neburon, } 8 \mathrm{lbs} . / \mathrm{A} \\
\text { 9. Neburon, } 16 \mathrm{lbs} . / \mathrm{A} \\
\text { 10. Atrazine, } 2 \mathrm{lbs} . / \mathrm{A} \\
\text { 11. Atrazine, } 4 \mathrm{lbs} . / \mathrm{A} \\
\text { 12. Atrazine, } 8 \mathrm{lbs} . / \mathrm{A} \\
\text { 13. Simazine, } 2 \mathrm{lbs} . / \mathrm{A} \\
\text { 14. Simazine, } 4 \mathrm{lbs} . / \mathrm{A} \\
\text { 15. Simazine, } 8 \mathrm{lbs} . / \mathrm{A} \\
\text { 16. Prometryne, } 2 \mathrm{lbs} . / \mathrm{A} \\
\text { 17. Prometryne, } 4 \mathrm{lbs} / \mathrm{A} \\
\text { 18. Prometryne, } 8 \mathrm{lbs} . / \mathrm{A} \\
\text { 19. Check }\end{array}$ & $\begin{array}{l}\text { Grams } \\
\text { 84.38 ab } \\
45.50 \text { defghij } \\
34.66 \text { fghijklmn } \\
44.52 \text { defghijk } \\
17.50 \text { lmn } \\
2.96 \text { o } \\
57.64 \text { cdefgh } \\
6.46 \text { lmn } \\
3.54 \text { o } \\
56.52 \text { defghi } \\
76.40 \text { abc } \\
37.74 \text { fghijklm } \\
58.92 \text { bedefg } \\
65.08 \text { abcde } \\
40.88 \text { fghijkl } \\
60.12 \text { abcdef } \\
59.58 \text { abcdefg } \\
84.87 \text { a } \\
73.40 \text { abcd }\end{array}$ & $\begin{array}{l}6.6 \text { cdefg } \\
5.2 \text { cdefg } \\
3.8 \text { defg } \\
5.2 \text { cdefg } \\
2.2 \mathrm{~g} \\
2.4 \mathrm{fg} \\
17.0 \mathrm{~b} \\
1.2 \mathrm{~g} \\
1.0 \mathrm{~g} \\
9.6 \mathrm{~cd} \\
10.4 \mathrm{c} \\
4.2 \mathrm{defg} \\
8.2 \mathrm{cde} \\
3.6 \mathrm{efg} \\
1.8 \mathrm{~g} \\
7.8 \mathrm{cdef} \\
2.8 \mathrm{efg} \\
5.6 \mathrm{cdefg} \\
26.8 \mathrm{a}\end{array}$ & $\begin{array}{l}\text { Grams } \\
1.3 \mathrm{~b} \\
1.5 \mathrm{~b} \\
1.2 \mathrm{~b} \\
2.9 \mathrm{~b} \\
0.3 \mathrm{~b} \\
0.1 \mathrm{~b} \\
2.9 \mathrm{~b} \\
0.3 \mathrm{~b} \\
0 \mathrm{~b} \\
7.7 \mathrm{~b} \\
1.9 \mathrm{~b} \\
0.5 \mathrm{~b} \\
1.3 \mathrm{~b} \\
0.9 \mathrm{~b} \\
0 \mathrm{~b} \\
0.8 \mathrm{~b} \\
0.3 \mathrm{~b} \\
0.8 \mathrm{~b} \\
17.2 \mathrm{a}\end{array}$ \\
\hline
\end{tabular}

1 Plants grown in black plastic bags containing Montones series soil.

2 Numbers within column followed by same letter do not differ significantly at 5percent level, using Duncan's Multiple Range Test.

especially the youngest ones. Later on, water-soaked areas developed at the tips and margins of the leaves. Leaves of severely affected plants tended to die back.

Plants receiving the 2 pound per acre rate had recovered by the end of the second month after treatments were initiated. All the seedlings treated with the other two concentrations, however, had succumbed 4 months after the initial treatment but, new shoots developed from the under. 
ground tuberous roots. This new growth showed no signs of damage. The symptoms just described closely resembled those reported for other plant species treated with Monuron (3).

2. Diuron: The effects of Diuron on yam seedlings were similar to those shown by plants submitted to Monuron. Wilting, yellowing, water-soaking and dying back occurred as in the case of plants treated with Monuron. Death of vines also occurred at the higher concentrations. Although similar in pattern, the characteristic toxic symptoms induced by substituted ureas were more intense than when Diuron was used. At the lowest concentration, 2 pounds, the appearance of plants improved somewhat 2 months after the initial treatments. Yam seedlings which received 4- and 8-pound applications failed to recover.

There was a drastic reduction in growth as the concentration of the herbicide was increased (table 1). Even the 2-pound rate significantly reduced the size of the roots as compared to the controls. The growth of roots under the 4- and 8-pound treatment was scant.

3. Neburon: Neburon at the lowest concentration had no detrimental. effect on the treated plants. Growth of vines was vigorous. They presented no visual indication of Neburon poisoning. This treatment also was not harmful to the growth of the tuberous roots as can be seen in table 1. However, when the Neburon dosage was raised from 4 to either 8 or 16 pounds per acre, symptoms developed similar to those displayed by the Monuron and Diuron treated plants. Roots were small and poorly developed.

\section{TRIAZINES}

1. Atrazine: Atrazine at doses of 2- and 4-pounds per acre produced mild yellow mottling in most of the younger leaves. Young affected leaves developed wavy margins. The effect was so pronounced in some cases that the leaves became completely distorted. New foliage was almost white in color. The toxic symptoms were most pronounced under the highest Atrazine concentration. Reduction of the leaf lamina also was evident. The ill effects of the lowest concentration were transitory because the plants presently recovered. Symptoms provoked by the 8-pound concentration persisted, however, until the end of the experiment. Although the application of Atrazine at rates of 2 and 4 pounds per acre caused visible symptoms of toxicity in the leaves, this was not reflected on the weight and size of the tuberous roots. On the other hand, there was an appreciable reduction in size and weight of roots of plants treated with 8 pounds per acre (table 1).

2. Simazine: Yellowing occurred on younger leaves of plants subjected to the highest Simazine rate. This became apparent about 15 days after 
the initiation of treatments. They were completely recovered, however, by the time the trial was terminated. The lowest and intermediate rates did not produce symptoms on the aerial parts of the treated plants and these looked as healthy and vigorous as the control plants. The roots harvested from the Simazine treated soil in general were of good and uniform size; however, yields were reduced significantly at the highest rate.

3. Prometryne: There were no injurious effects in plants treated with Prometryne regardless of the concentration used. The vines looked as healthy and vigorous as those left untreated. The roots produced by these plants were among the best. The results of these studies clearly indicate Prometryne to be the safest herbicide for controlling weeds associated with $D$. composita. A rate of 4 pounds per acre was found to be the treatment of choice because the herbicide is safe, effective, and economical at such a concentration. Field trials also have indicated that this treatment is effective for control of weeds in edible yam culture.

\section{SUMMARY}

A series of tests was conducted under greenhouse conditions to determine the relative usefulness of various herbicides for control of weeds in cortisone yam (Dioscorea composita Hemsl.) plantings. Monuron, Diuron, Neburon, Atrazine, Simazine and Prometryne each were applied at three different rates. Diuron and Monuron were found to be the most toxic of the substituted ureas. The most injurious of the triazines was Atrazine. Simazine, although somewhat toxic, was less so than than Atrazine. No evidence of Prometryne poisoning could be detected.

As expected, the number and weight of weeds were significantly lower in the test plots of plants treated with herbicides.

\section{RESUMEN}

Se realizó una prueba en invernadero a fin de comprobar la utilidad relativa de varios herbicidas para la erradiación de yerbajos en una siembra del ñame Dioscorea composita Hemsl., del cual se deriva la cortisona. Se usaron tres concentraciones de cada uno de los herbicidas Monuron, Diuron, Neburon, Atrazine, Simazine y Prometryne. Del grupo de las ureas sustituidas, el Diuron y el Monuron fueron los más tóxicos. En cambio, entre las triazinas el más perjudicial fue el Atrazine. El Simazine, aunque algo tóxico, lo fue menos que el Atrazine. No se observaron efectos perjudiciales causados por el Prometryne.

Tal como se esperaba, el número y el peso de los yerbajos fue significativamente más bajo en aquellas plantas que se trataron con los herbicidas. 


\section{LITERATURE CITED}

1. Cornell, D. S., Schubert, B. G., Gentry, H. S., and Dawley, W. O., The search for plant precursors of cortisone, Econ. Bot. 9 (4): 307-75, 1955.

2. Kasasian, L., Doheland, A., Promising weedicides for use in food crops, Caribbean Food Crops. Soc. Proc., Ind Ann. Meeting: 60-64, 1964.

3. González-Ibß̊nez, J., The use of preemergence herbicides for weed control around young coffee seedlings, J. Agr. Univ. P.R. 48 (1): 25-31, 1964. 